\title{
Effect of the Right Turning Movement to Road Urban Performance
}

\author{
Don Gaspar Noesaku da $\operatorname{Costa}^{1 *}$, Egidius Kalogo ${ }^{1}$, Donatus Arakian ${ }^{1}$, Mauritius I.R. \\ Naikofi $^{1}$, Christiani Chandra Manubulu ${ }^{1}$, Oktovianus Edvict Semiun ${ }^{1}$
}

${ }^{1}$ Study Program of Civil Engineering, Universitas Katolik Widya Mandira, Kupang, Indonesia

*Corresponding author.dnoesaku@gmail.com

\begin{abstract}
Although right turning movement frequency due to exiting- entering vehicles from or to the social-economic area, particularly located nearby an intersection, could influence travel delay and/or vehicle queuing but it has not been considered when determining both the roadway and intersection capacity and performance. Consequently, they may not describe the actual problems occurred there. Accordingly, this paper investigates it by describing risky situation occurred at two un-signalized intersections which consist of similar traffic and roadway situation. Effect of the right turning frequency to the degree of saturation, delay time and accident risk then was discussed. It was found that the level of side friction were in the low-level categories so that theoretically it does not affect the travel speed and/or degree of saturation. However, the obtained delay time was around $40 \mathrm{~s}$ so that it triggers riders to increase their approaching speed to avoid delay which in turn increases accident risk because at the same time the opposite riders insist on crossing the major stream with average critical gap acceptance of 20 $\mathrm{m}$. This strongly indicates that the right turning movement should be considered when determining road performance, urban speed limit, and traffic impact analysis
\end{abstract}

Keywords-accident risk, right turning movement, speeding, traffic impact analysis

\section{INTRODUCTION}

Determination of roadway and un-signalized intersection's capacities have been based on traffic volume and the type turning movement at each approach. Consequently, although there is access point located nearby an intersection, the effect of its right running movement has not been considered specifically to be variables that influence intersection capacity as well as performance as can be found in the Indonesian Highway Capacity Manual. As such Manual has been adopted from American Highway Capacity Manual, it is thought that an issues might also occurred at other places which use it.

Predominantly, intersection capacity was determined based on the right turning movements from its approaches merely whilst roadway capacity was calculated based on total entering-exiting frequency, including but neglecting the effect of the number of right turning movement. Consequently, they may not describe the actual problems there. In this particularly case, as degree of saturation / DS is a ratio of traffic volume to road capacity, neglecting the effect of right turning movement during determination of roadway capacity might end up inadequate description or analysis of concerned parameter actually occurred, especially delay time, queuing, and accident risk as it was identified at Palapa and Perintis Kemerdekaan I un-signalized intersections [1] as can be seen at Fig.1.
This paper focuses on identification effect of the right turning movement to DS, delay time, queuing, and accident risk around the entering-exiting gates of Oebobo and Oebufu gas stations as well as other social-economic nearby. Accident risk is also considered because although primary Indonesian Regulation stated that traffic flow, safety and comfort should be analysed when conducting Traffic Engineering and Management [2], its derivative regulation gives the possibility to analyse the effect of entering-exiting vehicles to traffic flow merely [3]. Consequently, almost Traffic Impact Analysis (TIA) product only recommends traffic engineering and/or management facilities suited to its DS category, whereas accident risk at a un-signalized intersection, including at entering-exiting gates of local activities, very much influenced by speed choice.

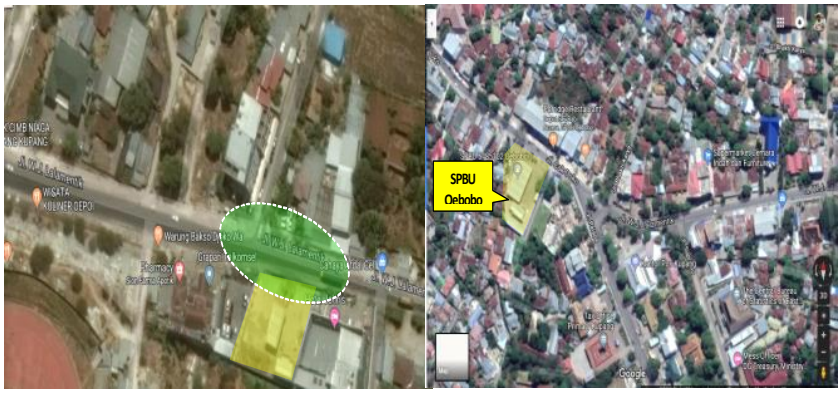

Figure 1. Study location characteristics 
Accordingly, this paper uses data and information gathered from two concerned files, i.e. the final reports of TIA of Oebobo and Oebufu Gas Stations [1]. Both of them having similar geometric (nearby intersection), traffic (major-minor composition) and road environment characteristics (type of land used). It is hoped that the important and strategic information that might be obtained could be used to develop future TIA directive.

\section{STUDY DESIGN}

As previously mentioned, all data and/or information is obtained from previously reported files classified based on its analysis' purposes as follows:

\subsection{Capacity and level of service analysis}

Investigated capacity not only at the un-signalized intersection but also at roadway in front of such Gas Stations. Calculation of roadway capacity was based on geometric and traffic characteristics such as type of roadway, the number of carriage lane and its width, roadside/shoulder width, split direction, the present of the separator, curb. Besides, a number of vehicles and/or pedestrian movement was also collected, consist of vehicles' parking and/or entering-exiting form minor road or gas station gates, as well as pedestrian cross and/or walk surround gas station's gates as well as intersections. Moreover, number of citizen of Kupang city was also used to describe riders' aggressively behaviour.

Meanwhile, calculation of un-signalized intersection capacity were based on the type of intersection (number of approaches lane and carriage width), the presence of separator and its width, and the ratios of turning movement, the ratio of minor to major traffic, as well as un-motorized vehicle ratio.

Further, although such observed gas station and unsignalized intersections was placed nearby, the roadway and intersection capacity were calculated separately. Even, there is no directive which suggests calculating the effect of the right-turning movement due to entering-exiting vehicles to and/or from social-economic activities placed along the roadway and nearby an intersection as previously shown in Fig.1. Consequently, their cumulative impacts could not be identified. It is assumed that this is why when the frequency of entering-exiting vehicles was in the low category, its influence to roadway and/or intersection capacity was also considered slight.

To ensure it, this paper correlates such entering and exiting frequency, particularly due to the right turning movement, to DS, delay time and crossing type of conflicts. This triggers by the fact that delay time and queuing length occurred due to the ratio of major to the minor stream of greater than $70 \%$. An undesired situation could trigger drivers' risky behaviour, such as insist on crossing although the distance headway between them and the upcoming vehicle, and its approaching speed was around $20 \mathrm{~m}$ and $55 \mathrm{~km} / \mathrm{h}$ respectively.

\subsection{Accident risk analysis}

Based on information about the critical gap acceptance and spot speed when the crossing conflict has occurred, the accident probability is calculated based on safety factor / SF [4], i.e. the ratio between critical crossing gap acceptance and predicted minimum stopping sight distance (an MSSD). Such MSSD model is determined by using the previous model developed by the same author which considers the effect of vehicle deceleration rate ability due to downshifting and braking. It can be seen that the model assumed that before braking riders usually decrease their vehicle speed using engine brake force so that braking distance is a function of approaching speed $\mathrm{V}_{1}$, instead of design speed as it has been recommended by AASHTO Edition 2011.

Subsequently, the predicted accident consequences could also be determined using a curve correlation between impact speed and fatal crash probability recommended by [5]. Such impact speed value could be calculated using a braking distance model recommended by AASHTO Edition 2011. However, the braking deceleration rate value used is its maximum ability, instead of a comfortable one as it was recommended by AASHTO Edition 2011, i.e. $3.4 \mathrm{~m} / \mathrm{s}^{2}$.

The use of such safety factor and curve correlation between impact speed and fatal crash probability was conducted since accident risk was a function of accident probability and its potential consequences (McCuen et al., 2011; Nassar, 1996). Therefore, if the SF is lower than 1.0 then it indicates the presence of accident probability [4], [7] whilst if the impact speed is greater than $43 \mathrm{~km} / \mathrm{h}$ or around $50 \mathrm{~km} / \mathrm{h}$ then the fatal crash probability was greater than $80 \%$ [5].

\section{RESULT AND DISCUSSION}

\subsection{Traffic flow characteristics}

\subsubsection{Traffic volume}

Figure 2 shows the characteristic of traffic flow around both Palapa (Oebobo) and Perintis Kemerdekaan I (Oebufu) intersections. Besides, from the result of turning movement volume survey it was found that the ratio of minor-major stream at both intersection was around $90-95 \%$. This strongly indicates that the possibility of delay and/or queuing due to right turning movement of entering-exiting vehicles from and/or to social-economic activities built surround such road segments are relatively very high.

Therefore, it could be implied that:

Effect of right turning movement to delay time and/or accident risk should be properly taking into account when describing road segments performance, instead of based on capacity and level of service only.

As the average delay time of entering-exiting vehicles increases by around $40 \mathrm{~s}$ due to the close headway distance of major stream, then the queuing probability due to such movements might trigger entering-exiting vehicle's driver to across major stream speculatively. 


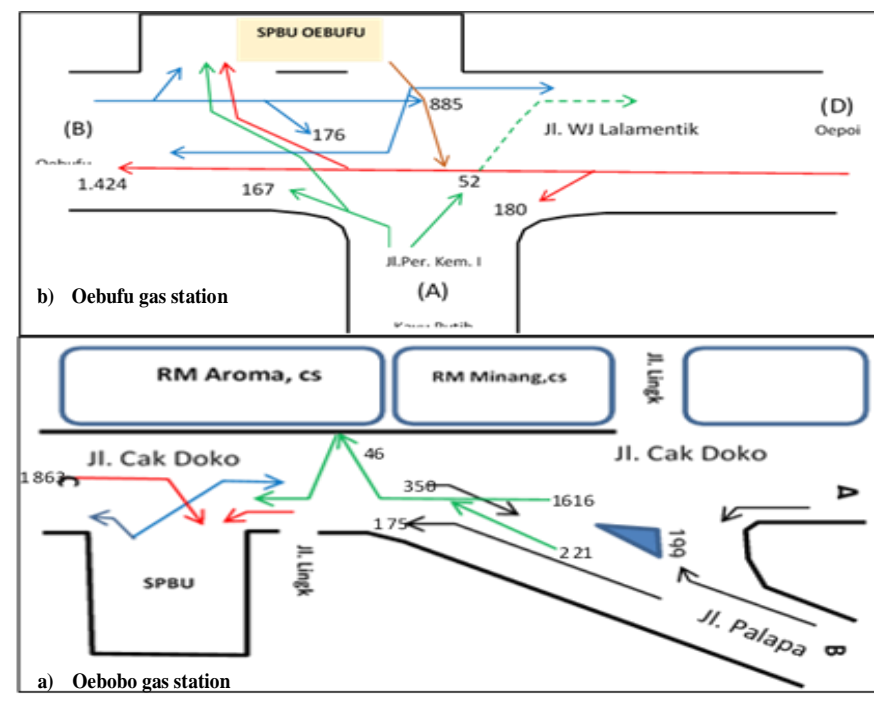

Figure 2. Traffic characteristics at study location

\subsubsection{Vehicle speed}

Vehicle speed represents riders riding ability and behaviour in percept their traveling environmental [8]. Speed choice is usually limited by the number of vehicle and pedestrian movements (side friction). It may also being influenced by such vehicle and/or pedestrian types of movements such as right turning, etc. The average vehicle speed when entering the intersection area and/or entering-exiting gates of observed gas station was around $45 \mathrm{~km} / \mathrm{h}$ (Std.Dev.8, max.72). Consequently, as the critical crossing gap acceptance or ASSD was $20 \mathrm{~m}$, similar with situation occurred at Yogyakarta [9], only riders in average and above average braking ability category might avoid crash if their approaching speed is greater than $60 \mathrm{~km} / \mathrm{h}$. However it should be noted that with such approaching speed, the possibility of riders in below average braking ability is relatively high because previous study reported that fatal crash might occur when the impact speed was greater than $43 \mathrm{~km} / \mathrm{h}$ [10].

This phenomenon confirms the finding of previous concerned study which reported that although speeding behaviour is a personality matter [11], but it might be intervened [8] because this study indicates that it may also influenced by another specific traffic characteristics, i.e. delay time due to right turning movement ratio. For instantly solution, the potential crossing type of conflicts should be managed by using particular officer. Such person in charge should be established by the gas station owner. Besides, it is required to consider the effect of right turning movement and critical gap acceptance when determining speed limit at unsignalised intersection, including at entering-exiting gates of the centre of social-economic activities. The indication of required speed limit determination guideline improvement was also mentioned by previous researchers [12]-[14]. However, it should be noted that such researchers recommended it based on braking ability characteristics. That is why the determination of speed limit is previously recommended to take into account the effect of braking ability [4] and determinant variables behind speed behaviour [15].

\subsubsection{Road side friction}

These following Tables of 1 and 2 show not only the number but also type of manoeuvre of the entering-exiting vehicles from-to each gas station. Such type of manoeuvre, particularly right turning movement, might influence traffic volume, speed and density significantly. In this particularly case, it should be noted that since the ratio of major-minor stream was approximately $90-95 \%$ this phenomena strongly indicate that the critical gap acceptance might occur due to some drivers being bored and insist on crossing although the distance headway was around 20-25 m, similar with the result of previous concerned study [4], [16]. This confirms that accident risk due to such crossing type of conflict should also be taken into account proportionally.

The increasing of right turning movement in the evening occurred due to the refill of fuel tank of local public transport means. However, according to the Indonesian Highway Capacity Manual 1997 such increasing was still in the low level category of roadside friction so that its influence to the adjustment factor which is used to determine the roadway capacity has been also considered by way of little.

Table I. Roadside Triction due to Trip Attraction and Generation of Oebufu Gas Station

\begin{tabular}{|r|c|c|c|c|c|c|c|c|c}
\hline Description & \multicolumn{3}{|c|}{ Entering } & \multicolumn{3}{c|}{ Exiting } & \multicolumn{3}{|c}{ Quantity } \\
\hline $\begin{array}{l}\text { Entering - } \\
\text { exiting } \\
\text { vehicles }\end{array}$ & $\begin{array}{c}\text { From } \\
\text { Tofa } \\
\text { (LT) }\end{array}$ & $\begin{array}{c}\text { From } \\
\text { Oepoi } \\
\text { (RT) }\end{array}$ & $\begin{array}{c}\text { From Per. } \\
\text { Kem I } \\
\text { (RT) }\end{array}$ & $\begin{array}{c}\text { To } \\
\text { Tofa } \\
\text { (RT) }\end{array}$ & $\begin{array}{c}\text { To Per. } \\
\text { Kem I } \\
\text { (RT) }\end{array}$ & $\begin{array}{c}\text { To } \\
\text { Oepoi } \\
(\mathrm{LT})\end{array}$ & RT [\%] & LT & Total \\
\hline Morning & 12 & 2 & 2 & 2 & 4 & 8 & $6[23]$ & 20 & 26 \\
\hline Afternoon & 10 & 4 & 5 & 3 & 4 & 11 & $12[30]$ & 41 & 39 \\
\hline Evening & 8 & 7 & 3 & 5 & 7 & 2 & $15[60]$ & 10 & 25 \\
\hline
\end{tabular}

Note: $\mathrm{LT}=$ left turn, $\mathrm{RT}=$ right turn

Table II. Roadside Friction due to Trip Attraction and Generation of Oebobo Gas Station

\begin{tabular}{|c|c|c|c|c|c|c|c|c|}
\hline $\mathbf{N}$ & Narrative & \multicolumn{2}{|c|}{ Entering } & \multicolumn{2}{|c|}{ Exiting } & \multicolumn{3}{|c|}{ Quantity } \\
\hline 1 & $\begin{array}{l}\text { Entering - } \\
\text { exiting } \\
\text { vehicles (gas } \\
\text { station) }\end{array}$ & $\begin{array}{c}\text { From } \\
\text { Oebobo \& } \\
\text { Palapa } \\
\text { (LT) } \\
\end{array}$ & $\begin{array}{l}\text { From } \\
\text { Oetete } \\
\text { (RT) }\end{array}$ & $\begin{array}{c}\text { T0 } \\
\text { Oebobo + } \\
\text { Palapa } \\
\text { (RT) } \\
\end{array}$ & $\begin{array}{c}\text { T0 } \\
\text { Oetete } \\
\text { (LT) }\end{array}$ & RT [\%] & LT & Total \\
\hline & Morning & 6 & 1 & 3 & 4 & $4[28]$ & 10 & 14 \\
\hline & Afternoon & 14 & 4 & 6 & 11 & $10[28]$ & 25 & 35 \\
\hline & Evening & 18 & 10 & 7 & 15 & 17 [51] & 33 & 40 \\
\hline 2 & $\begin{array}{l}\text { Entering- } \\
\text { exiting } \\
\text { vehicles } \\
\text { (Aroma } \\
\text { restaurant, et. } \\
\text { al) }\end{array}$ & $\begin{array}{l}\text { From } \\
\text { Oebobo + } \\
\text { Palapa } \\
\text { (RT) }\end{array}$ & $\begin{array}{l}\text { From } \\
\text { Oetete } \\
\text { (LT) }\end{array}$ & $\begin{array}{c}\text { To } \\
\text { Oebobo + } \\
\text { Palapa } \\
\text { (LT) }\end{array}$ & $\begin{array}{c}\text { T0 } \\
\text { Oetete } \\
\text { (RT) }\end{array}$ & $\operatorname{RT}[\%]$ & LT & Total \\
\hline & Morning & 5 & 6 & 4 & 2 & $5[33]$ & 7 & 12 \\
\hline & Afternoon & 28 & 16 & 10 & 24 & $52[67]$ & 26 & 78 \\
\hline & Evening & 6 & 14 & 4 & 6 & 12 [40] & 18 & 30 \\
\hline \multicolumn{6}{|c|}{ Peak_morning } & $9[35]$ & 17 & 26 \\
\hline \multicolumn{6}{|c|}{ Peak_afternoon } & 62 [60] & 51 & 103 \\
\hline \multicolumn{6}{|c|}{ Peak_evening } & $29[36]$ & 51 & 80 \\
\hline
\end{tabular}


It can be seen that although the right turning movement at this study location also increase in the afternoon but according to Indonesian Highway Manual Capacity the side friction level was still in the low category level. Besides, as previously mentioned, the delay time is varying, i.e. around $40 \mathrm{~s}$ in the morning and afternoon period but less than $30 \mathrm{~s}$ in the evening period, so that based on traffic engineering and management point of view, with such side friction level and delay time, the roadway performance at both Oebobo and Oebufu gas station as well as Palapa and Perintis Kemerdekaan I intersections was in the acceptable category. However, from the traffic safety point of view, the average critical gap acceptance value of $20 \mathrm{~m}$ could trigger accident probability and/or fatality because some riders traveling with speed of around $60 \mathrm{~km} / \mathrm{h}$. In this particularly case, only riders with average and above average braking ability might avoid crash safely as it was previously reported by da Costa, et al (2018).

\subsection{Effect of right turning movement to roadway and/or intersection performance}

Table III and IV show that today, theoretically, there is no traffic issue as both of their level of service (LoS) are D, and the delay time as well as queuing percentage are lower than $30 \mathrm{~s}$ and $50 \%$ respectively (in the acceptable range of category). In fact, the occurred queuing length and delay time are around $10 \mathrm{~m}$ and greater than $30 \mathrm{~s}$ respectively so that it influences the average speed and trigger major traffic divers, especially motorcyclist, to exceed their approaching speed when recognise the presence of opposite crossing vehicles.

Table III. Existing and Prediction Capacity and DS of Observed Roadway

\begin{tabular}{|l|c|c|c|c|c|c|}
\hline $\begin{array}{l}\mathbf{N} \\
\mathbf{0}\end{array}$ & Description & $\begin{array}{c}\text { Peak } \\
\text { Volume Q } \\
\text { (pcu/h) }\end{array}$ & $\begin{array}{c}\text { Capacity } \\
\text { C (pcu/h) }\end{array}$ & $\begin{array}{c}\text { Degree of } \\
\text { saturation } \\
\text { DS }\end{array}$ & $\begin{array}{c}\text { Running } \\
\text { Speed } \\
(\mathbf{k m} / \mathbf{h})\end{array}$ & LoS \\
\hline \multicolumn{6}{|l|}{ Cak Doko roadway } \\
\hline 1 & Existing 2019 & 1.646 & 2.170 & 0.76 & 50 & D \\
\hline 2 & 2024 & 2.101 & 2.170 & 0.97 & 30 & E \\
\hline \multicolumn{7}{|l|}{ WJ Lalamentik roadway } \\
\hline 1 & Existing 2019 & 1.997 & 2.637 & 0.76 & 50 & D \\
\hline 2 & 2024 & 2.800 & 2.637 & 1.06 & 30 & E \\
\hline
\end{tabular}

Table IV. Existing and Prediction Performance of the Observed un-signalized Intersection

\begin{tabular}{|c|c|c|c|c|}
\hline No & Description & DS & Delay (det/pcu) & Queue probability (\%) \\
\hline \multicolumn{5}{|c|}{ Palapa intersection } \\
\hline 1 & Existing 2019 & 0,83 & 12,31 & $27,74-54,93$ \\
\hline 2 & Prediction 2024 & 1,06 & 14,88 & $45,25-90,05$ \\
\hline \multicolumn{5}{|c|}{ Perintis Kemerdekaan I intersection } \\
\hline 1 & Existing 2019 & 0,826 & 12,311 & $27-55$ \\
\hline 2 & Prediction 2024 & 1,16 & 15,89 & $54-100$ \\
\hline
\end{tabular}

Use of these types of performance indicators might end up unsuitable and/or inappropriate traffic management necessity because it cannot be correlated to traffic delay time due to vehicle's right turning movement of social-economic activities placed along the roadway and/or nearby intersection. In addition, it was also cannot be correlated to accident risk due to crossing type of conflicts occurred by impassion entering-exiting vehicle's driver. On the other hand, this risky behaviour is similar with concerned situation occurred on Yogyakarta [4], [16] which strongly indicates that accident risk due to right turning movement should be seriously considered to be the primary indicator when determining roadway performance analysis and/or evaluation as described above.

Therefore it could be imply that the determination of roadway and/or intersection capacity should taking into account not only the effect of right turning movement (at the entering-exiting gates of social-economic activities placed surround it), but also the approaching speed and braking ability of major stream of traffic riders, as well as critical gap acceptance of entering-exiting vehicles drivers [4], [17], comprehensively and simultaneously. Consequently, although the obtained DS at road link was lower than 0.75 , but the decreasing in speed, or increasing of delay time, queuing length, and accident risk level due to the right turning frequency should be considered when determining traffic engineering and/or management at roadway with high density of mixed land-used, high traffic volume, and aggressive riders as can be easily found in many developing countries.

Further, the guideline of Indonesia Traffic Impact Analysis should be improved by considering traffic safety analysis to be a mandatory condition because thus far it was only determined based on traffic engineering and management criteria. Even, it should also consider the traffic comfortable aspects which is usually neglected. In addition, since such risky situation might occur due to cumulative effect, it is thought that in the near future speed limit determination should be also improved by taking into account the effect of braking ability, determinant variables behind speed behaviour and right turning movement ratio simultaneously. Such requirement confirms previous suggestion due to similar risky situation occurred at un-signalized intersections [14], [15], [17].

\section{CONCLUSION}

The conclusion that could be drawn based on previous result and discussion are:

1. The right-turning movement should be considered when determining road network performance

2. It is required to improve the Indonesian Guideline of Speed Limit Determination, particularly at the entering-exiting gates and/or un-signalized intersection, and Driving Licensing Mechanism based on braking ability due to right turning movement volume at such risky locations 


\section{ACKNOWLEDGMENT}

The authors would like to thank to The Center of Research and Community Services of Universitas Katolik Widya Mandira Kupang for the research grant through the "Hibah Unwira" scheme 2019, and to PT. Piet Mitra Jaya Kupang for the Traffic Impact Analysis relief fund.

\section{REFERENCES}

[1] D. G. N. da Costa, "ANDALALIN SPBU Oebobo \& Oebufu. Disampaikan dalam Diskusi TIA di Dinas Perhubungan Provinsi NTT," 2019, no. April, unpublished.

[2] Pemerintah Republik Indonesia, "Peraturan Pemerintah Republik Indonesia Nomor 32 Tahun 2011 tentang Manajemen dan rekayasa analisis dampak lalu lintas serta manajemen kebutuhan lalu lintas.” Jakarta, 2011.

[3] Kementrian Perhubungan, "Peraturan Mentri Perhubungan Republik Indonesia Nomor PM 75 Tahun 2015 tentang penyelenggaraan analisis dampak lalu lintas." 2015.

[4] D. G. N. da Costa, S. Malkhamah, and L. B. Suparma, "Use of the safety factor and margin of safety in motorcyclist accident risk management," Int. J. Technol., vol. 9, no. 4, pp. 37-50, 2018.

[5] GRSP, "Speed management: a road safety manual for decision-makers and practitioners.," Global Road Safety Partnership, Geneva, Switzerland, 2008.

[6] S. A. Nassar, "Integrated road accident risk model (ARM)," University of Waterloo, 1996.

[7] T. Smith, S. Garet, and J. Cicchino, "The effect of sight distance training on the visual scanning of motorcycle riders: a preliminary look," Washington DC, 2013.

[8] S. Malkhamah, L. B. Suparma, and D. G. N. da Costa, "Considering the effect of motorcyclist risk tolerance in accident risk management : a preliminary study," vol. 20, no. 2, pp. 78-85, 2018.

[9] D. G. N. da Costa, S. Malkhamah, and L. B. Suparma, "Penggunaan celah penyeberangan kritis sebagai parameter indikator peluang kecelakaan di simpang tak bersinyal," J. Transp., in press. .

[10] S. Mihradi, H. Golfianto, A. I. Mahyudin, and T. Dirgantara, "Head injury analysis of vehicle occupant in frontal crash simulation : Case Study of ITB 's Formula SAE Race Car," J. Eng. Technol. Sci., vol. 49, no. 4, pp. 534-545, 2017.

[11] E. Constantinou, G. Panayiotou, N. Konstantinou, A. Loutsiou-Ladd, and A. Kapardis, "Risky and aggressive driving in young adults: Personality matters," Accid. Anal. Prev., vol. 43, no. 4, pp. 1323-1331, 2011.

[12] W. Bartlett, A. Baxter, and N. Robar, "Motorcycle braking test: I.P.T.M. Data Through 2006," Accid. Reconstr. J., vol. July-Augus, no., pp. 19-21, 2007.

[13] M. Winkelbauer and K. Vavryn, "Braking performance of experienced and novice motorcycle riders - Results of a Field Study," 2015.

[14] S. Malkhamah, L. B. Suparma, and D. G. N. da Costa, "Accident risk management based on rider braking capability," Int. J. Adv. Sci. Eng. Inf. Technol., in press.

[15] D. G. N. da Costa, S. Malkhamah, and L. B. Suparma, "Determinant variables behind motorcyclist daily favoured speed," in the 11th APTE conference, 2018, in press.

[16] D. G. N. da Costa, S. Malkhamah, and L. B. Suparma, "A systematic approach in developing an accident risk reduction scheme," in 6th International Annual Engineering Seminar.ISBN 978-1-5090-0741-7, 2016, pp. $13-18$.

[17] D. G. N. da Costa, S. Malkhamah, and L. B. Suparma, "Accident risk management strategy at un-signalized intersection," in E3S Web of Conferences 76, 03011 (2019), 2019, vol. 3011, pp. 1-5. 